\title{
Teaching English for Children through Translation Perspective
}

\author{
I Gusti Ayu Agung Dian Susanthi ${ }^{1}$, Anak Agung Istri Manik Warmadewi ${ }^{1}$, Dewa Ayu Kadek Claria ${ }^{1}$, I Gusti \\ Ngurah Adi Rajistha ${ }^{1} \&$ Ni Putu Intan Mayang Sari ${ }^{1}$ \\ ${ }^{1}$ University of Warmadewa, Bali-Indonesia, Indonesia \\ Correspondence: I Gusti Ayu Agung Dian Susanthi, University of Warmadewa, Bali-Indonesia, Indonesia. Tel: \\ 628-1238-577-117. E-mail: gungdian03@gmail.com
}

Received: November 13, 2019; Accepted: December 2, 2019; Published: December 3, 2019

\begin{abstract}
There are some ways in teaching second language for children, one of them is by introducing folklore in English. The teacher must view that the shifts may occur in teaching second language. There are some famous Indonesian folklore that have been translated into English that can be introduced for the children. In introducing the English language for children, the Indonesian folklore which is translated English is very important to be learnt, in Indonesian, for instance, English as the second language, so that there are various books which are translated into English, Folklore is one important way to learn second language. There are hundreds folklore of Indonesian and some of them are translated into English. An Indonesian language folklore may be translated into various languages like English, Japanese, etc. In teaching English for children, the teacher must understand that every language will have different structure, so that the shift may occur. In the translation, shifts can happen because one language may have different structure, rules or formation. Shifts are the phenomenon which can be found in translation, it is interesting to analyze the shifts occur in Indonesian folklore, because folklore is one media to learn English for Indonesian children. A popular Indonesian folklore entitled Bawang Merah and Bawang Putih Story were chosen to be analyzed in this study.
\end{abstract}

Keywords: teaching english, translation, shifts

\section{Intorduction}

\subsection{Introduce the Problem}

There are various languages in this world. In doing communication, we can use various languages such as Chinese, Japanese, French, Germany, English, and so on. Those languages are the examples of popular languages. English is the language that mostly spoken by the people all over the world, it may be as the first or second language. So that, it is also known as the international language. It is found that English is spoken in daily conversation, poetry, lecture, etc. Sometimes English can be translated into some languages. Translation is not an easy job, in doing translation there must be some procedures to be noticed. Translation covers the study of micro linguistics and macro linguistics in both languages SL and the TL. The form can be changed, however the meaning must be well transferred. So that the translation involves micro and macro linguistics. In terms of micro linguistics there will be shifting in structure, sound adjustment in the TL, meanwhile, in terms of macro linguistics, there will be transferring the culture or adjustment the culture of the SL into the TL. Many various kinds of translation can be found in publication media, such as book, journal, etc. Folklore is an important way to learn second language. There are hundreds folklore of Indonesian and some of them are converted into various languages. Some English folklores can be converted into various languages like Indonesian, Chinese, and so on. In doing the translation shifts can happen because one language may have different structure, rules or formation.

Shift can be found in translation process, shift can represent the changing in translation. Since translation involves different languages, so the changing can happen at the lower level of language or at the higher level. Shift may deal with different forms that can represent the same meaning in the SL and the TL. (Catford 1978, pp. 76).

According to the explanation above, it is interesting to discuss the shifts occur in Indonesian folklore, because folklore is one media to learn English for Indonesian children. A popular Indonesian folklore entitled Bawang Merah and Bawang Putih Story were chosen to be analyzed in this study.

\subsection{Importance of the Problem}

The importance of this study is to reveal the shifts phenomenon happen in translating Indonesian folklore into English. This research can be used as the guideline or reference for the translator in translating the other Indonesian 
folklore into English. This research can also be used by the other researcher as the reference in analyzing the shifts in translation. In addition, this research also enrich the reader knowledge about the variations of Indonesian English translation shifts.

\subsection{Relevance Scholarships}

Several works of the scholar focusing on the investigation of shifts were reviewed in this section. To review the relevant works, is important to be done since they are closely related to this study. Catford (1965, pp. 73) stated that shifts deal with the departure of the SL from the formal correspondence to the TL. There are two kinds of shifts: level shifts and category shifts. He also proposed that translation is as a process of converting message from a SL into a TL. He proposed the terms SL is as Source Language and TL is as Target Language.

\section{Level Shifts}

Level shift occurs when the linguistic level of the SL item has its equivalent in the different level of the TL translation (Catford, 1965: 73). In addition, he claimed that the level shift may be in terms of grammar. The discussion can be seen as in below

Examples:

1) SL: she is studying hard.

TL: dia sedang belajar keras

2) SL: she has studied hard.

TL: dia sudah belajar keras

It can be seen that the grammatical form, namely tobe $+V$-ing (the form is English Present Continuous Tense) in the SL and the translation in the TL is sedang. Then, it is found that the level shift in the example above is proved in terms of grammar in the SL, it is converted into lexis in the TL.

Level shift is found in the second example above, it is proved by looking the form has + Perfect Tense in the SL is converted in the TL by converting into the word sudah.

\section{Category Shifts}

Category shift may be classified into four, namely: structure shift, class shift, unit shift and intra system shift (Catford 1965, pp. 76). They are presented individually as in below.

\section{Structure Shifts}

Structure shifts can be proved in if there are two languages with different structure. In addition, the SL and TL must have formal correspondence.

The discussions are as follows:

1) SL: she cleans herself.

$$
\mathrm{S} \quad \mathrm{O} \quad \mathrm{O}
$$

TL: dia mandi

$$
\mathrm{S} \quad \mathrm{P}
$$

2) SL: the glass is by the window.

$$
\text { M H }
$$

TL: gelas itu ada di dekat jendela

$\mathrm{H} \quad \mathrm{M}$

It can be proved that there are different structure of sentence level and phrase level in the SL and the TL. The languages may have structure such as:(1) She $(\mathrm{S})$, cleans $(\mathrm{V})$ and herself $(\mathrm{O})$. the target language translation has different sentence structure, namely dia $(\mathrm{S})$ and mandi $(\mathrm{P})$. The translation shows or it is proved that the element object herself in the source language is not stated in target language.

Data (2) shows that the phrase of both languages have different structure from the glass which is converted into gelas itu. There are Modifier-Head (MH) in the pattern of the phrase the glass in the source language (MH) which consists of modifier the and head glass. In Indonesian, the pattern of gelas itu, has the pattern of Head-Modifier (HM) pattern; gelas is as the head, while itu is the modifier. 


\section{Class Shifts}

Class shift, happens when the SL has different class in the TL (Catford 1965, pp. 78).

And the examples of class shifts are as follows:

1) SL: Mario menunggu dengan cemas.

TL: Mario waits anxiously.

2) SL: Mereka menangis dengan keras.

TL: They cry loudly.

Those examples above show, Indonesian is the SL and TL is English. Data (1), shows the word cemas is an adjective in the source language; and the function of the word anxiously in the TL is as an adverb. So, cemas (adjective) in the SL is the equivalent translation of the adverb anxiously in the TL.

Class shift is also found in the (2) example. It occurs from the adjective which is converted into adverb. The word keras in the source language is an adjective and the translation in the target language is loudly which is as an adverb.

\section{Unit/Rank Shifts}

Catford explained that unit shift is a changing in terms of rank. Unit shift can occur as a changing in terms of rank. Phrase was known as a group of words without a verb: The white dog and a quarter to ten can be categorized as phrases (Oxford dictionary, pp. 868). In the examples above the phrases have a higher position (unit/rank) than word. The examples of unit shifts are presented as follows:

Examples:

1) SL: This clock is so luxurious.

TL: Jam dinding anda sangat mewah

2) SL: There is a cinema over there.

\section{TL: Ada bioskop sana.}

Unit shift in translation shows a changing in terms of rank in the data (1) above. It is seen, the word clock ( the rank is lower) in the SL which is converted into a phrase jam dinding (the rank is higher) in the target language.

Data (2) also shows the same case namely unit shift, the noun phrase a cinema (the rank is higher) in SL is converted into a word bioskop in which the rank is lower in the TL.

\section{Intra-System Shifts}

The shift happens internally, within a system is called as Intra-system shift. The examples of intra system shifts are presented as follows. Examples:

1) SL: The Gentlemen watch the parade.

TL: Pria itu menonton parade.

SL: The young ladies are in the yoga class.

TL: gadis remaja ada di kelas yoga.

Those two examples show that there is transferring of meaning process from SL into TL. The word gentlemen can be correspond with a repetition of the word pria (pria-pria) or para + pria in Indonesian, Indonesian language system indicates it in a singular form pria. The form for the young ladies can correspond through a repetition of the word gadis (gadis-gadis) or the translator can use additional word para + gadis in Indonesian, however the singular form system gadis is still used in the Indonesian language.

Larson in Meaning-Based Translation explained the definition of translation by some explanation. it is claimed that in translation the form can be changed when we use the form of a language, we refer to the use of the actual words, phrases, etc., the languages can be spoken or written. Those forms can be called as the language's surface structure (Larson 1984, pp. 3). In addition, the SL is the form from which the translation is formed and the form into which it is to be changed is known as target language (Larson 1984, pp. 3).

\section{Method}

The methodology of this research were divided into the methodology of collecting data, analyzing the data then the findings were presented. The data were taken from Indonesian folklore entitled Bawang Merah and Bawang 
Putih. This book was chosen because it contains the shifts. Since the research was not conducted in the field, this research was a library research. The observation was applied by observing thoroughly the texts of the Indonesian and English versions. The method was implemented by note taking method to collect the relevant data. The data were analyzed based on the problems which mainly focused on translation shifts. The data were analyzed qualitatively. In presenting the analyzed data can be drawn by informal and formal method. The analyzed data are presented by using word description. Firstly, the data were classified into the categories of shifts, then data were analyzed based on the categories of shifts.

\section{Results}

In the previous sub discussion has explained about translation and translation shifts; in this sub discussion the examples and the shifts analysis phenomenon that were found in the data are presented in this study. The data of this present research were from an Indonesian story entitled bawang merah dan bawang putih and its English version of the story, the title is bawang merah and bawang putih. The shifts analysis phenomenon that were found in the story are presented in detail in this following discussion.

\subsection{Level Shifts}

It is seen that level shift occurs if the item of SL and the TL have different level. This shift commonly occurs at the level of structure of source language and the target language is in form of lexicon. The data source shows two kinds of level shift namely : The first is in the marker of Past Continuous (was/were $+-i n g$ ) and the second is, in the marker of Past Perfect (had + Past Participle marker)

\subsubsection{Past Perfect Simple}

The source of the data of this paper shows that the shifts of level is in the form of Past Perfect (had + Past Participle marker). The detail of analysis is presented as follows.

Examples:

SL: it was found an old woman who had previously found the clothes

TL: terdapat seorang wanita tua yang sebelumnya sudah menemukan kain itu

Level shift occurs in example above. The SL is converted in lexis sudah in the TL. The form of the source language is had + Past Participle marker. It is seen that the shift in terms of level, namely from grammar to lexis. It is because the form to express Past Perfect Tense, to express this kind of situation English and Indonesian have different way, In Indonesian we can say sudah to indicate the activity that happened before a particular time in the past. In other words, in Indonesian, it can be say by sudah. So, between the SL and TL we can find shift in terms of level (grammar to lexis). However, the meaning of both languages can be transferred well.

\subsubsection{Past Continuous Tense (was/were $+V$-ing) converted into sedang}

Data of this present study shows the shifts in terms of level in the marker of Past Continuous (was/were + -ing) shifted into sedang was presented in this present research. The detail discussion can be seen as follows.

\section{SL: One day, Bawang Merah was crying}

TL: Pada suatu hari Bawang merah sedang menangis.

It is seen that shift in terms of level occurs in the data above. The English form of was $+V$-ing in the SL is converted into sedang which can be classified as a lexis in the TL. So that, the level shift occurs from grammar to lexis. English and Indonesian have different way to say sedang, the form of Past Continuous Tense or a progress activity in the past can be expressed by was/were + -ing. One day, Bawang Merah was crying, the lexis (crying) which is done by the subject Bawang Merah was in the form of progress or ongoing activity in the past. There is no certain form in Indonesian to state this activity. It can be stated by sedang in Indonesian. So, it is found that there is shift in terms of level in the SL and TL. In this example, the equivalence of the translation is good because the meaning can be transferred well.

\subsection{Category Shifts}

Category shifts is also the type of shifts. Category shifts can be a changing the formal form in translation. It is known four types of shifts in terms of category, namely shift in terms of structure, shift in terms of class, shift in terms of unit and intra-system shift. Those all types of category shifts were found.

\subsubsection{Structure Shifts}

This structural shift happens because of changes in the composition of the grammar or the sequence of words in the sentence. This shift can happen because of the style of the translator or in other words it follows a certain style 
of writing (style). Shift in terms of structure occurs when the structure of SL and the TL are different. The source of data of this study shows the occurrence of structure shifts. The detail analysis can be seen as follows.

\section{SL: In the ancient time, lived a little family \\ TL: Pada zaman dahulu, ada sebuah keluarga kecil}

We can see that the word arrangement of the SL and TL are not in the same arrangement. In the example above, the little family which is translated into keluarga kecil have different structure, namely in the SL, the pattern of the noun phrase of little family little (modifier), and family (head). Meanwhile in Indonesian, keluarga (head), and kecil (modifier). So that, there are different word arrangement both in the SL and the TL. However the meaning is transferred well.

\subsubsection{Class Shifts}

The class shift may happen where the word class is shifted (type of word) in the translation. These word classes may vary from one language to another. The detail discussion can be seen as follows.

\section{SL: one day, Bawang Putih went shopping to the market}

TL: pada suatu hari, Bawang Putih membeli sesuatu ke ke pasar

The analysis:

From the data above, it is found that there is shift in terms of class happens. The word shopping in the SL is a noun and it is converted into membeli. The word membeli can be classified as a verb in the target language. We can see that the shift in terms of class occurs. However, the meaning of the SL to the TL is well translated.

\subsubsection{Unit Shifts}

It is known that unit shift is rank changing, in this case the equivalent translation of a unit at one rank in the SL is different rank of unit in the target language (Catford 1965, pp. 79).. It is found in data source, the unit shift may occur from word to phrase and vice versa.

Example :

$$
\begin{aligned}
& \text { SL: "I don't know" She said } \\
& \text { TL: "Entahlah" kata Bawang Merah }
\end{aligned}
$$

The analysis:

It is found that, the unit shift occurs in the data. The word "I don't know" is translated into "Entahlah". It is seen that the SL has a different unit with the TL translation. The data shows the unit shift occurs form the clausal level to lexical level (higher level to lower level). However, having viewed on the translation, it is seen that the translation from the clausal level I don't know into lexicl entahlah is good because the meaning is well translated.

\subsubsection{Intra-System Shifts}

Intra-system shift may happen internally, it can occur within a system. Example :

\section{SL: After that, Bawang Putih lived happily with gold and many gems.}

TL: Ia hidup bahagia dengan emas dan banyak permata yang ia punya.

The analysis:

The data shows the phrase "many gems" that consists of quantifier many and the nominal head "gems". The plural marker in english that is suffix $-\mathbf{s}$ must follow the noun since it is more that one gem reffered in the phrase. In Indonesian, the expression of plural form is shown from the quantifier "banyak" (many), which is followed by "permata" (gem). Unlike its English version, in which the noun must be in plural form, the Indonesian noun followed by plural form will be redundant. Thus many gems in translated into banyak permata, not banyak permata-permata.

\section{Discussion}

Based on the shifts analysis it is found that there were translation shifts found in the data source, namely shift in terms of level and shift in terms of category.

In addition, it is found that shifts may happen in the translation because both of the SL and the TL have different structure. English as the source language has tenses such as past tense, simple present, ect. Meanwhile Indonesian does not have that kind of tenses. In addition Indonesian has its own way or culture to express meaning 
Further research is very important to be conducted, especially about shifts, Shifts are very interesting to be discussed because it also can be found in daily life, in short story, novel, etc. The shifts theory can be introduced to English teacher in kindergarten, elementary school in other to be easily to teach the student about English and its translation in the Indonesian. It is suggested to do more research about shifts in other story.

\section{References}

Catford, J. C. (1965). A Linguistic Theory of Translation. London: Oxford University Press.

Dian Susanthi \& I Gusti Ayu Agung, et al. (2019). The Procedures of Translating Abbreviation in English Medical Texts into Indonesian. E-Journal of Linguistics Unud, 13(1), 1-12.

Larson, M. L. (1984). Meaning-Based Translation. New York: University Press of America.

Newmark, P. (1981). Approach to translation. Oxford: Pregamon Press, Ltd.

Newmark, P. (1988). A Text Book of Translation. London:Prentice Hall.

Nida, E. A. (1975). Language Structure and Translation. United States of America: Standford University

Nida, E. A., \& Taber, C. R. (1969). The Theory and Practice of Translation. Leiden: E. J. Brill. https://doi.org/10.2307/411434

Venuti, L. (1995). The Translator's Invisibility: A History of Translation. London: Routledge. https://doi.org/10.4324/9780203360064

Venuti, L. (1998). The Scandals of translation:Towards an Ethics of Difference. London: Routledge. https://doi.org/10.4324/9780203269701

Venuti, L. (2000). The Translation Studies Reader. London: Routledge. https://doi.org/10.4324/9780203446621

Vinay, J. P., \& Darbelnet, J. I. L. V. (2000). A Methodology for Translation. London: Routledge.

\section{Copyrights}

Copyright for this article is retained by the author(s), with first publication rights granted to the journal.

This is an open-access article distributed under the terms and conditions of the Creative Commons Attribution license (http://creativecommons.org/licenses/by/4.0/). 